\title{
Genotype-expression interactions for BDNF across human brain regions
}

\author{
Patrick Devlin ${ }^{{ }^{*}}$ (D) Xueyuan $\mathrm{CaO}^{2}$ and Ansley Grimes Stanfill ${ }^{2}$ (D)
}

\begin{abstract}
Background: Genetic variations in brain-derived neurotrophic factor (BDNF) are associated with various psychiatric disorders including depression, obsessive-compulsive disorder, substance use disorders, and schizophrenia; altered gene expression triggered by these genetic variants may serve to create these phenotypes. But genotypeexpression interactions for this gene have not been well-studied across brain regions relevant for psychiatric disorders.

Results: At false discovery rate (FDR) of 10\% ( $q<0.1$ ), a total of 61 SNPs were associated with BDNF expression in cerebellum ( $n=209), 55$ SNPs in cortex $(n=205), 48$ SNPs in nucleus accumbens $(n=202), 47$ SNPs in caudate $(n=194)$, and 58 SNPs in cerebellar hemisphere $(n=175)$. We identified a set of 30 SNPs in 2 haplotype blocks that were associated with alterations in expression for each of these 5 regions. The first haplotype block included variants associated in the literature with panic disorders (rs16917204), addiction (rs11030104), bipolar disorder (rs16917237/rs2049045), and obsessive-compulsive disorder (rs6265). Likewise, variants in the second haplotype block have been previously associated with disorders such as nicotine addiction, major depressive disorder (rs988748), and epilepsy (rs6484320/rs7103411).

Conclusions: This work supports the association of variants within BDNF for expression changes in these key brain regions that may contribute to common behavioral phenotypes for disorders of compulsion, impulsivity, and addiction. These SNPs should be further investigated as possible therapeutic and diagnostic targets to aid in management of these and other psychiatric disorders.
\end{abstract}

Keywords: BDNF, Genetic expression, Brain, Human subjects, Cognitive disorders

\section{Background}

Brain-derived neurotrophic factor (gene symbol: $B D N F$ ) is a widely expressed protein in the nervous tissues of the brain and spinal cord, as it is responsible for the growth, maintenance, and maturation of nerve cells [1]. This protein is classified as a neurotrophin due to the important role it plays in regulating neuronal function and development, done so through highly regulated expression that ensures correct cell-to-cell communication

\footnotetext{
* Correspondence: Pdevlin2@uthsc.edu

${ }^{1}$ Department of Anatomy and Neurobiology, College of Graduate Health Sciences, University of Tennessee Health Science Center, 920 Madison Ave. \#807, Memphis, TN 38163, USA

Full list of author information is available at the end of the article
}

and viability. The BDNF protein and its receptor, tropomyosin receptor kinase $B(\operatorname{TrkB})$, are involved in several intracellular signaling pathways including the phospholipase Cg (PLCg), phosphoinositide 3-kinase (PI3K), and mitogen-activated protein kinase/extracellular signalregulated protein kinase (MAPK/ERK) pathways [2]. Each of these pathways is important for neuronal signaling activities that will vary by expression across brain regions, including neuroregeneration, neurosynaptic plasticity, memory formation, and regulation of cognitive functions [3, 4]. Any significant change in the amount of expression can influence this signaling and thus result in downstream behavioral effects.

(c) The Author(s). 2021 Open Access This article is licensed under a Creative Commons Attribution 4.0 International License, which permits use, sharing, adaptation, distribution and reproduction in any medium or format, as long as you give appropriate credit to the original author(s) and the source, provide a link to the Creative Commons licence, and indicate if changes were made. The images or other third party material in this article are included in the article's Creative Commons licence, unless indicated otherwise in a credit line to the material. If material is not included in the article's Creative Commons licence and your intended use is not permitted by statutory regulation or exceeds the permitted use, you will need to obtain permission directly from the copyright holder. To view a copy of this licence, visit http://creativecommons.org/licenses/by/4.0/ The Creative Commons Public Domain Dedication waiver (http://creativecommons.org/publicdomain/zero/1.0/) applies to the data made available in this article, unless otherwise stated in a credit line to the data. 
Given these broad signaling effects, it is not surprising that altered $B D N F$ expression has also been implicated in development of neuropsychiatric disorders such as depression, obsessive-compulsive disorder, substance use disorders, and schizophrenia [5]. Indeed, alterations in BDNF peripheral blood (leukocyte) gene expression and protein levels have been shown to be a significant biomarker for many of these disorders [6, 7]. Genetic variations within $B D N F$ may induce inappropriate expression and result in breakdown of proper cell signaling, and several variants in this gene have similarly been associated with various neuropsychiatric disorders $[8$, 9]. Conversely, restoration to normal homeostatic conditions has been shown to improve the symptoms caused by these conditions, as occurs when BDNFtargeted neurotrophic pharmaceuticals are given to patients [10].

However, BDNF expression and function are highly tissue-dependent. Due to the important regulatory role it plays, this protein can be found in most areas of the brain relevant to psychiatric disorders, including the cortex, cerebellum, caudate, hippocampus, and others. Expression alterations will vary by disease and by brain region/location [5]. For instance, in schizophrenia, prefrontal cortex BDNF protein levels were found to be significantly lower in patients versus healthy controls [1113], while decreases in BDNF levels in the temporal cortex and occipital cortex, and increases in the parietal cortex and frontal cortex, were found in postmortem samples [14]. Despite these findings, and other evidence that expression changes are associated with psychiatric behavioral profiles, it is still unclear how genotypic variation is associated with expression of $B D N F$ across these relevant human brain regions. Here, we will address this gap by using the Genotype-Tissue Expression (GTEx) database to determine the associations of variations in $B D N F$ with expression across five brain regions relevant to neuropsychiatric conditions. Understanding these differences will allow better comprehension of regional variations in expression and how genetic variation contributes to differential expression by brain region. This information is the first step toward future work in $B D N F$ signal regulation and the development of related therapeutics.

\section{Results}

Human subject and tissue sample data

Expression levels from a total of 985 tissue samples from 300 unique subjects were matched to genetic sequencing data for $B D N F$ for our 5 brain regions of interest (Table 1). Note that not every person donated samples from every brain region, leading to a discrepancy in the table between the numbers of tissue samples that were available for each region. Summary data for the four demographic factors of our included subjects (age, sex, race, and BMI) are provided in Table 2.

\section{Association between BDNF expression by demographics}

Age, sex, and BMI were not associated with BDNF expression for any of our five brain regions of interest in this sample $(p>0.08$; Table 3$)$. Race was associated with $B D N F$ expression in the caudate tissue samples $(p=$ 0.01 ), but this association was not found for the remaining regions.

\section{Differential BDNF expression between brain regions}

Next, we investigated the pairwise differential expression among the brain regions of interest. The expression of $B D N F$ in cerebellar hemisphere was significantly higher than that in cerebellum, cortex, caudate and nucleus accumbens $(p<0.0001$, Table 4; Fig. 1$)$.

Note that the $p$-value of the signed rank test compares median expression between two regions.

\section{Genotype-expression in brain tissue}

A total of 61 SNPs in $B D N F$ were associated with expression in the cerebellum, 55 SNPs in cortex, 48 SNPs in nucleus accumbens, 47 SNPs in caudate, and 58 SNPs in cerebellar hemisphere at FDR level of 0.1 (Supplementary Table 1). Thirty of these SNPs were shared and thus significant for $B D N F$ expression across all five brain regions $(p<0.000015$, Fig. 2$)$. These SNPs were aggregated into two main haplotype blocks, with eight SNPs (rs16917204, rs11030104, rs7103411, rs16917237, rs6484320, rs988748, rs2049045, rs6265) associated in the literature with various psychiatric disorders (Fig. 3; Table 5). Table 6 provides the detailed direction and strength of associations measured by Spearman correlation across the 5 brain regions for the 30 SNPs.

Table 1 BDNF expression data by tissue

\begin{tabular}{lllll}
\hline Brain Tissue Region & Number of subjects & $\begin{array}{l}\text { Median } \\
\text { (TPM) }\end{array}$ & $\begin{array}{l}\text { Fraction } \\
\text { (0 TPM) }\end{array}$ & $\begin{array}{l}\text { Subjects } \\
\text { (> 0 TPM) }\end{array}$ \\
\hline Cerebellum & 209 & 24 & 0.177 & 172 \\
Cortex & 205 & 21 & 0.278 & 148 \\
Nucleus accumbens & 202 & 17 & 0.2772 & 146 \\
Caudate & 194 & 18.5 & 0.2629 & 143 \\
Cerebellar Hemisphere & 175 & 25 & 0.24 & 133 \\
\hline
\end{tabular}


Table 2 Demographics of human subjects $(N=300)$

\begin{tabular}{lll}
\hline Variables & Level & $\mathbf{n}$ or mean $(\%$ or range) \\
\hline Sex & Female & $86(28.7 \%)$ \\
& Male & $214(71.3 \%)$ \\
Race & American Indian or Alaska Native & $1(0.3 \%)$ \\
& Asian & $1(0.3 \%)$ \\
& Black & $26(8.7 \%)$ \\
& White & $272(90.7 \%)$ \\
Age & & $60.5(53-65)$ \\
BMl & & $27.34(24.4-30.9)$ \\
\hline
\end{tabular}

\section{Discussion}

Our results are some of the first to demonstrate genotype-expression interactions across multiple human brain regions relevant for neuropsychiatric conditions. Our work suggests the physiological (here, gene expression) result of genetic $B D N F$ variation that may contribute to specific psychiatric disorders in symptomatology and behavioral phenotypes. In turn, future investigations of these SNPs will lead to a better understanding of the complexity of BDNF protein signaling in the human brain and will inform future therapeutics in this area.

\section{Association between BDNF expression and clinical and demographic factors}

Surprisingly, the GTEx sample did not demonstrate a relationship between the four available demographic factors and expression in these brain regions. BDNF expression has been shown in other research to vary by sex, possibly due to sexual dimorphism in hormonal

Table 3 Association of BDNF expression with demographic factors

\begin{tabular}{|c|c|c|c|c|c|}
\hline Region & Demographic & & $\mathbf{n}$ & Median_IQR & $p$-value \\
\hline \multirow[t]{6}{*}{ Cerebellum } & Sex & Female & $48(27.9 \%)$ & $30(13.75 \sim 45.25)$ & 0.97 \\
\hline & & Male & $124(72.1 \%)$ & $30.5(9.75 \sim 50.25)$ & \\
\hline & Race & Black & 17 (9.9\%) & $18(13 \sim 33)$ & 0.13 \\
\hline & & White & $154(89.5 \%)$ & $32(12.25 \sim 50.75)$ & \\
\hline & Age & & 172 & -0.03 & 0.70 \\
\hline & BMI & & 172 & -0.0063 & 0.93 \\
\hline \multirow[t]{6}{*}{ Cortex } & Sex & Female & 49 (33.1\%) & $27(14 \sim 39)$ & 0.18 \\
\hline & & Male & 99 (66.9\%) & $33(17.5 \sim 46)$ & \\
\hline & Race & Black & $17(11.5 \%)$ & $22(4 \sim 38)$ & 0.08 \\
\hline & & White & $130(87.8 \%)$ & $31.5(18.25 \sim 45)$ & \\
\hline & Age & & 148 & -0.0238 & 0.77 \\
\hline & BMI & & 148 & $-9 e-04$ & 0.99 \\
\hline \multirow[t]{6}{*}{ Nucleus accumbens } & Sex & Female & $42(28.8 \%)$ & $25.5(12.25 \sim 42.75)$ & 0.90 \\
\hline & & Male & $104(71.2 \%)$ & $28(15 \sim 41.25)$ & \\
\hline & Race & Black & $13(9 \%)$ & $20(3 \sim 35)$ & 0.14 \\
\hline & & White & $131(90.3 \%)$ & $28(15 \sim 43)$ & \\
\hline & Age & & 146 & 0.0486 & 0.56 \\
\hline & BMI & & 146 & 0.0778 & 0.35 \\
\hline \multirow[t]{6}{*}{ Caudate } & Sex & Female & $38(26.6 \%)$ & $33(18.25 \sim 55)$ & 0.14 \\
\hline & & Male & $105(73.4 \%)$ & $28(14 \sim 40)$ & \\
\hline & Race & Black & 14 (9.9\%) & $15.5(2.25 \sim 26.5)$ & 0.01 \\
\hline & & White & $127(89.4 \%)$ & $33(17 \sim 46)$ & \\
\hline & Age & & 143 & 0.031 & 0.71 \\
\hline & BMl & & 143 & 0.0031 & 0.97 \\
\hline \multirow[t]{6}{*}{ Cerebellar Hemisphere } & Sex & Female & $37(27.8 \%)$ & $44(16 \sim 70)$ & 0.79 \\
\hline & & Male & $96(72.2 \%)$ & $42(18.75 \sim 69.5)$ & \\
\hline & Race & Black & $11(8.3 \%)$ & $25(16 \sim 40)$ & 0.09 \\
\hline & & White & 121 (91\%) & $45(19 \sim 72)$ & \\
\hline & Age & & 133 & -0.0192 & 0.83 \\
\hline & BMI & & 133 & 0.1449 & 0.10 \\
\hline
\end{tabular}


Table 4 BDNF differential expression among five brain tissues

\begin{tabular}{|c|c|c|c|c|}
\hline Tissues & Cortex & Nucleus accumbens & Caudate & Cerebellar Hemisphere \\
\hline Cerebellum & 0.209094 & 0.036692 & 0.036883 & $3.1 \mathrm{e}-05$ \\
\hline Cortex & & 0.033255 & 0.370596 & $6.9 \mathrm{e}-05$ \\
\hline Nucleus accumbens & & & 0.491501 & $4.6 e-05$ \\
\hline Caudate & & & & 7e-06 \\
\hline
\end{tabular}

status, enzymatic activities, and body weight (BMI) as well as fat/lean mass composition differences by sex [32]. For example, sex differences in estrogen regulation have been shown to alter $B D N F$ gene expression. Females have been shown to have a lower baseline $B D N F$ gene expression than males in the cortex as well as CA1 regions of the hippocampus and dentate gyrus [33, 34]. We did not observe such significant difference in any of the regions $(p>0.08$; Table 3$)$. While the samples available in this database are extensive, such hormonal and enzymatic contributors may be more influential in an invivo system than in the post-mortem tissue samples we are analyzing here and could potentially lead to this lack of association.

Increased age has also been strongly associated with a decrease in $B D N F$ expression in the cortex, potentially from neuronal death during the aging process $[35,36]$. Similar changes have been found in hippocampal volume and BDNF expression [37]. However, our work here did not demonstrate such effects, possibly due to the limited age range of our subjects between 53 and 65 years old, often before such volumetric loss becomes significant

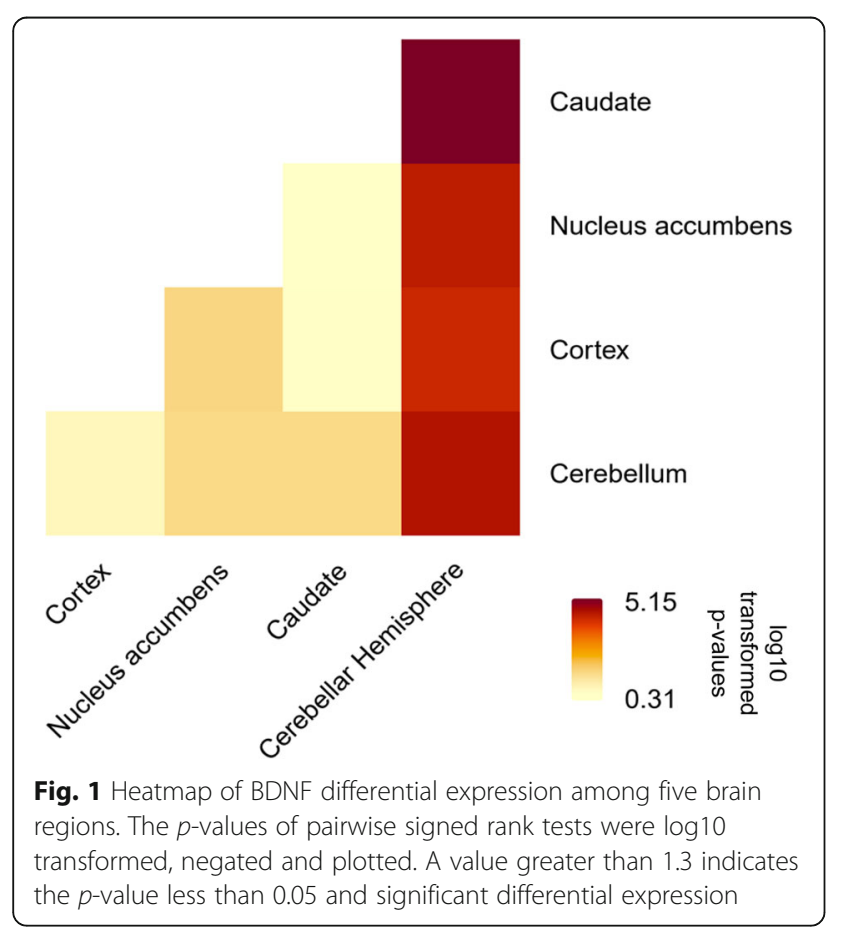

(Table 3). Although research has shown that significant alteration of gene expression precedes the psychiatric phenotype and often occurs in the prenatal stages [38], it is one limitation of our dataset that data from prenatal subjects are not available.

\section{Differential expression of BDNF across brain regions}

Our results demonstrate that there are significant variations in $B D N F$ expression across each of our brain regions of interest. Expression of BDNF in the cerebellar hemisphere was significantly higher than the cerebellum $(p=3.1 \mathrm{e}-05)$, cortex $(p=6.9 \mathrm{e}-05)$, nucleus accumbens $(p=4.6 \mathrm{e}-05)$, and caudate $(p=7 \mathrm{e}-06)$ (Table 4 ; Fig. 1$)$. This suggests that the signaling activities of BDNF may be more robust in these areas of the brain, creating functional changes in these areas. Although there is a dearth of literature to support such associations in human brain regions, our results are consistent with findings in mouse models, with higher levels of BDNF mRNA being found in the cerebral cortex and cerebellum [39].

Further, there is a logic to these findings, as for example, the cerebellum requires greater $B D N F$ expression to aid in transport during complex functions such as

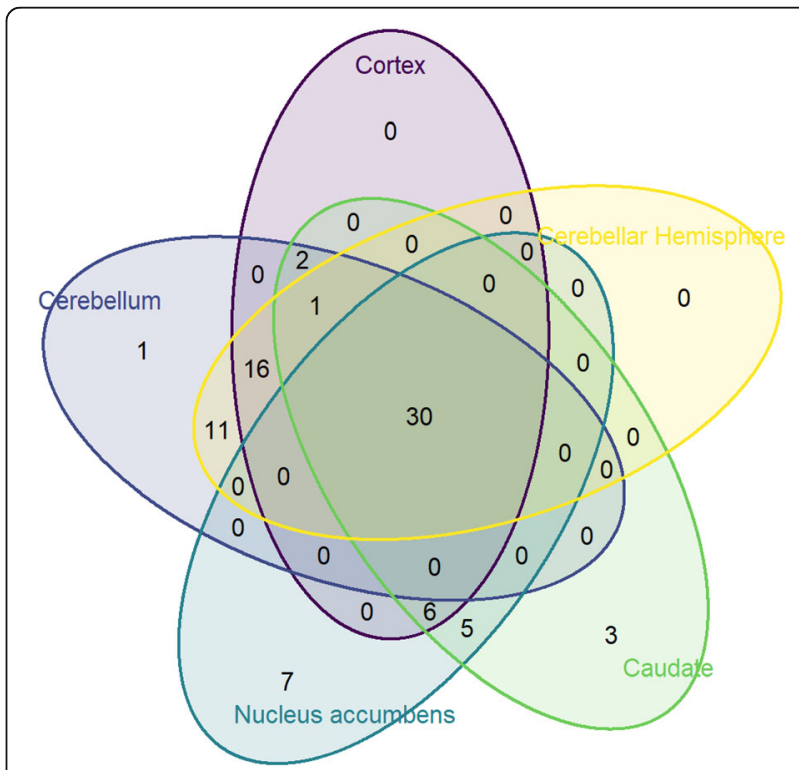

Fig. 2 Venn diagram of Cis-expression Quantitative Trait Loci (eQTL) of BDNF across five human brain regions 


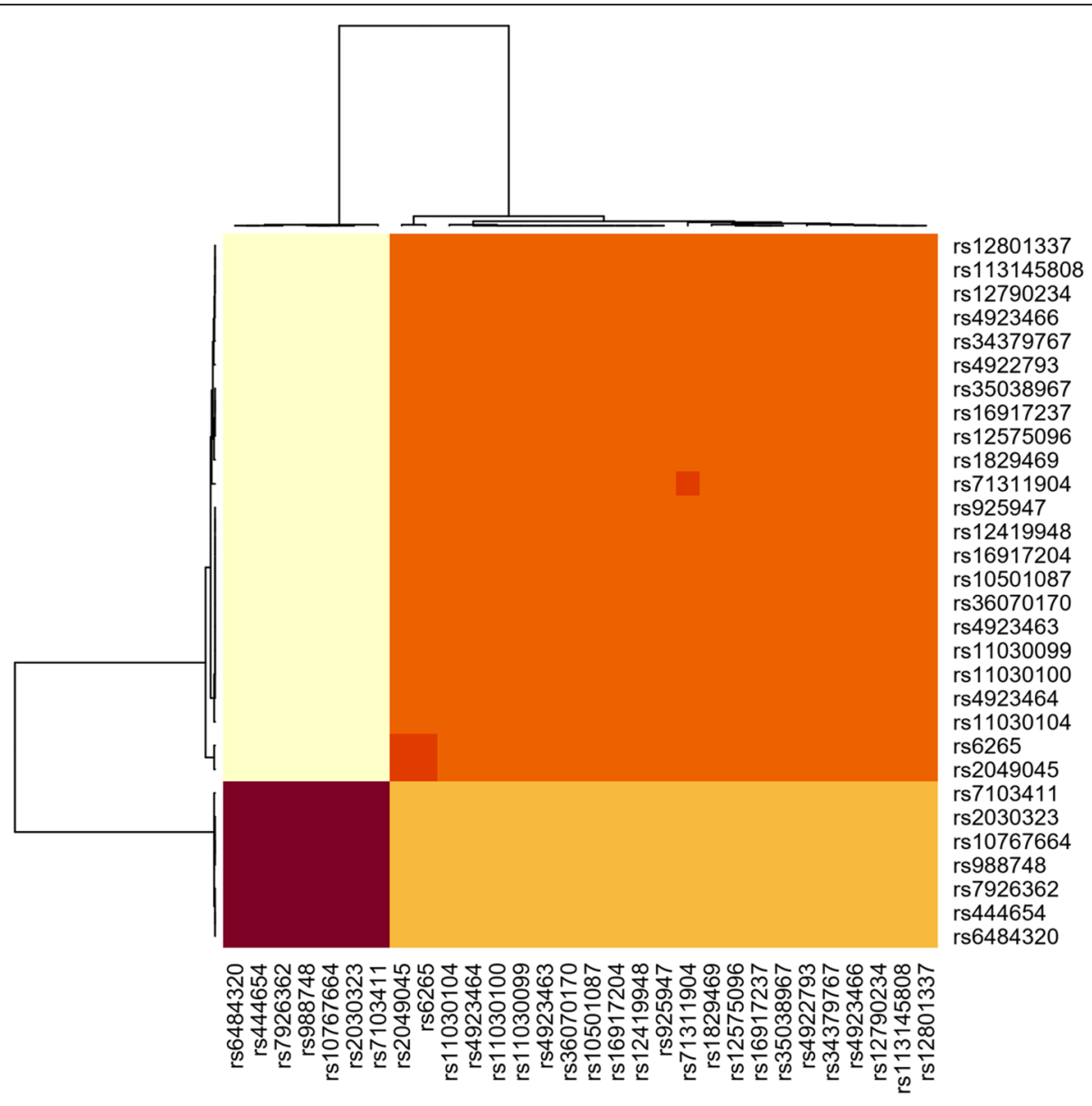

Fig. 3 Haplotype groups of significant SNPs shared across the brain regions of interest

motor coordination and information-processing. Clinically, dysfunction in these brain regions is associated with various neuropsychiatric disorders. The large amounts of $B D N F$ localization in these areas demonstrates their importance in signaling to maintain neuropsychiatric functions. For instance, decreased expression of $B D N F$ occurs in the prefrontal cortex and nucleus accumbens (NAc) of human patients with major depression [40, 41], while bipolar disorder has been associated with decreased $B D N F$ levels and grey matter reductions in various subcortical structures implicated in emotional processing [42-45]. A greater understanding of the clinical implications of these differences may provide unique insight to the overall role of $B D N F$ in the neurological system.

\section{SNPs associated with expression across brains regions}

While there are region specific genotype-expression associations, there are also commonalities in genotypeexpression that are shared across all five regions, a finding which suggests that different areas of the brain may share common signaling pathways and harness together common expression changes that are associated with neuropsychiatric phenotypes. While many of our shared SNPs showed little clinical relevance in the literature to date, several were shown to play a role in the development of various types of psychiatric disorders-from cognitive based conditions, to bipolar disorder, depression, and epilepsy. Several others were also shown to play a role in addictive behaviors (Table 5). For example, rs16917204 has been found to be associated with panic disorder, Alzheimer's, and schizophrenia [16-18]. But the influence of a particular SNP upon phenotype is dependent on the expression alteration and the influence on the neurosignaling behavior of that local region upon other regions of the brain.

This phenomenon is clearly illustrated by the effect of Val66Met (rs6265), a common polymorphism in the $B D N F$ pathway, which was found to have genotypeexpression effects across our most significant five brain regions. In both post-traumatic stress disorder and bipolar disorder, rs6265 is a locus for trauma-induced epigenetic regulation, which alters expression to reduce $B D N F$ production, and is thus a contributor to the onset 
Table 5 Clinically relevant SNPs associated with BDNF expression across brain regions of interest

\begin{tabular}{|c|c|c|c|}
\hline SNP rsID & 1000 Genome Frequency & Location & Associated Disorder or Phenotype \\
\hline \multirow[t]{4}{*}{ rs16917204 } & \multirow[t]{4}{*}{$C=0.2298$} & \multirow{4}{*}{$\begin{array}{l}\text { Intron, gene body, } \\
\text { Chromosome 11, } \\
\text { Position: } 27646808\end{array}$} & - Methamphetamine abuse [15] \\
\hline & & & • Panic disorders [16] \\
\hline & & & • Alzheimers Disease [17] \\
\hline & & & • Schizophrenia [18] \\
\hline \multirow[t]{4}{*}{ rs6265 } & \multirow[t]{4}{*}{$T=0.2013$} & \multirow{4}{*}{$\begin{array}{l}\text { Exon, gene body, } \\
\text { Chromosome 11, } \\
\text { Position: } 27658369\end{array}$} & • Major depressive disorder [19] \\
\hline & & & • Bipolar disorder [20] \\
\hline & & & • Obsessive-compulsive disorder [21] \\
\hline & & & • Alzheimer's disease [22] \\
\hline \multirow[t]{3}{*}{ rs11030104 } & \multirow[t]{3}{*}{$G=0.2226$} & \multirow{3}{*}{$\begin{array}{l}\text { Intron, gene body, } \\
\text { Chromosome 11, } \\
\text { Position: } 27662970\end{array}$} & • Increased BMI [23] \\
\hline & & & - BMI and Smoking [24] \\
\hline & & & • Alzheimer's disease [22] \\
\hline rs7103411 & $C=0.2470$ & $\begin{array}{l}\text { Intron, gene body, } \\
\text { Chromosome } 11 \\
\text { Position: } 27678578\end{array}$ & • Epilepsy [25] \\
\hline \multirow[t]{2}{*}{ rs16917237 } & \multirow[t]{2}{*}{$T=0.2214$} & \multirow{2}{*}{$\begin{array}{l}\text { Intron, gene body, } \\
\text { Chromosome } 11, \\
\text { Position: } 27680836\end{array}$} & • Eating disorders, increased BMI [26] \\
\hline & & & • Bipolar disorder [27] \\
\hline \multirow[t]{2}{*}{ rs6484320 } & \multirow[t]{2}{*}{$T=0.2468$} & \multirow{2}{*}{$\begin{array}{l}\text { Intron, gene body, } \\
\text { Chromosome } 11 \\
\text { Position: } 27681641\end{array}$} & • Epilepsy (in Fragile x-syndrome) [28] \\
\hline & & & - Smoking and nicotine addiction [29] \\
\hline \multirow[t]{2}{*}{ rs988748 } & \multirow[t]{2}{*}{$C=0.2430$} & \multirow{2}{*}{$\begin{array}{l}\text { Intron, gene body, } \\
\text { Chromosome } 11 \\
\text { Position: } 27703198\end{array}$} & • Major depressive disorder [19] \\
\hline & & & • Smoking and nicotine addiction [29] \\
\hline \multirow[t]{3}{*}{ rs2049045 } & \multirow[t]{3}{*}{$C=0.0629$} & \multirow{3}{*}{$\begin{array}{l}\text { Intron, gene body, } \\
\text { Chromosome 11, } \\
\text { Position: } 27672694\end{array}$} & - Alzheimer's disease-related depression [30] \\
\hline & & & • Bipolar disorder [31] \\
\hline & & & • Alzheimer's disease [22] \\
\hline
\end{tabular}

of both illnesses through the mediation of the neurotrophic receptor tyrosine kinase 2 (NTRK2) [46-48].

Indeed, rs6265 is one of the most widely studied and understood SNPs responsible for BDNF expression changes. In this SNP, the substitution of a valine to methionine at codon 66 affects gene expression by resulting in the dysregulation of microRNA (such as miR-146b), which in turn affects downstream mRNA levels resulting in altered protein expression [49, 50]. This change in protein expression effects integral processes such as synaptic plasticity which results in many of the cognitive orders associated with this SNP [51, 52]. Understanding the underlying processes responsible for the phenotypic presentation of observed disorders can better provide insight into the role of specific SNPs and inform possible targets for medical interventions in humans.

Others of our SNPs of interest create common phenotypes in a different manner. As an example, the SNPs rs7103411 and rs6484320 are both located on Chromosome 11, both intronic, and both associated with epilepsy (Table 5). The SNP rs7103411 is significantly associated with cryptogenic and symptomatic epilepsy [25], while rs6484320 is specifically associated with epilepsy occurring in Fragile X syndrome [28]. However, the mechanism of action to create the common seizure phenotype is different, as rs6484320 does not itself directly affect $B D N F$ expression through its receptors but instead plays this role through a linkage disequilibrium with Val66Met [53]. The SNP rs7103411 directly affects expression through receptor disruption and influences the abnormal signaling behavior seen in epilepsy [25].

The majority of our SNPs are found on the noncoding regions of the gene body, which may affect splicing or gene expression as cis-regulatory elements. However, these SNPs have been demonstrated to alter transcription or affect splicing of the pre-RNA transcript $[54,55]$. Many "silent" SNPs can cause the generation of proteins with the same amino acid sequences, but which have different structural and functional properties by changing conformation and protein activity/substrate specificity [56, 57]. These phenomenon have been illustrated in the associations of major depressive disorder with rs988748, and in schizophrenia rs16917204 [53, 58].

Our SNPs can also interact in a synergistic manner to create the observed BDNF expression changes, as which occurs in Alzheimer's disease. The SNPs rs11030104 and rs2049045 are found between exons 6 and 7. On the 
Table 6 The association of 30 SNPs with BDNF expression in each of the five regions

\begin{tabular}{|c|c|c|c|c|c|c|c|c|c|c|c|c|c|}
\hline \multirow[b]{2}{*}{ dbSNP_ID } & \multirow[b]{2}{*}{ REF } & \multirow[b]{2}{*}{ ALT } & \multirow{2}{*}{$\begin{array}{l}\text { ALT } \\
\text { Freq }\end{array}$} & \multicolumn{2}{|c|}{ Cerebellum } & \multicolumn{2}{|l|}{ Cortex } & \multicolumn{2}{|c|}{ Nucleus accumbens } & \multicolumn{2}{|l|}{ Caudate } & \multicolumn{2}{|c|}{ Cerebellar Hemisphere } \\
\hline & & & & Corr_r & $P$ value & Corr_r & $P$ value & Corr_r & $P$ value & Corr_r & $P$ value & Corr_r & $P$ value \\
\hline rs2049045 & G & C & 0.1531 & 0.5676 & $4.73 \mathrm{E}-16$ & 0.5758 & $1.93 \mathrm{E}-14$ & 0.4088 & $3.02 \mathrm{E}-07$ & 0.4473 & $2.14 \mathrm{E}-08$ & 0.5266 & $7.51 \mathrm{E}-11$ \\
\hline rs6265 & C & $\mathrm{T}$ & 0.1555 & 0.584 & $4.12 \mathrm{E}-17$ & 0.5974 & 1.10E-15 & 0.4084 & 3.09E-07 & 0.4666 & 4.27E-09 & 0.5475 & $9.10 \mathrm{E}-12$ \\
\hline rs1829469 & $A$ & G & 0.1675 & 0.5391 & $3.97 \mathrm{E}-14$ & 0.4754 & 1.17E-09 & 0.3581 & $9.10 \mathrm{E}-06$ & 0.3918 & $1.43 \mathrm{E}-06$ & 0.5226 & $1.30 \mathrm{E}-10$ \\
\hline rs16917237 & G & $\mathrm{T}$ & 0.1699 & 0.5185 & $3.21 \mathrm{E}-13$ & 0.4789 & $7.42 \mathrm{E}-10$ & 0.3506 & $1.44 \mathrm{E}-05$ & 0.4025 & $6.23 \mathrm{E}-07$ & 0.5127 & $2.81 \mathrm{E}-10$ \\
\hline rs35038967 & $\mathrm{T}$ & A & 0.1699 & 0.5185 & $3.21 \mathrm{E}-13$ & 0.4789 & $7.42 \mathrm{E}-10$ & 0.3506 & $1.44 \mathrm{E}-05$ & 0.4025 & $6.23 \mathrm{E}-07$ & 0.5127 & $2.81 \mathrm{E}-10$ \\
\hline rs12575096 & A & G & 0.1699 & 0.5185 & $3.21 \mathrm{E}-13$ & 0.4789 & $7.42 \mathrm{E}-10$ & 0.3506 & $1.44 \mathrm{E}-05$ & 0.4025 & $6.23 \mathrm{E}-07$ & 0.5127 & $2.81 \mathrm{E}-10$ \\
\hline rs11030104 & A & G & 0.1722 & 0.5452 & $1.05 \mathrm{E}-14$ & 0.4978 & $1.21 \mathrm{E}-10$ & 0.3672 & $5.12 \mathrm{E}-06$ & 0.3867 & $1.84 \mathrm{E}-06$ & 0.5254 & $8.45 \mathrm{E}-11$ \\
\hline rs71311904 & C & CCATTT & 0.1722 & 0.4743 & $4.96 \mathrm{E}-11$ & 0.455 & $6.28 \mathrm{E}-09$ & 0.3561 & 1.03E-05 & 0.4131 & $2.93 \mathrm{E}-07$ & 0.4562 & 3.43E-08 \\
\hline rs34379767 & G & A & 0.1731 & 0.5075 & $1.20 \mathrm{E}-12$ & 0.476 & 1.11E-09 & 0.3694 & 4.47E-06 & 0.4268 & $1.18 \mathrm{E}-07$ & 0.4994 & $9.39 \mathrm{E}-10$ \\
\hline rs4923466 & C & A & 0.1731 & 0.5086 & $1.22 \mathrm{E}-12$ & 0.4866 & 4.13E-10 & 0.3694 & 4.47E-06 & 0.4334 & 6.39E-08 & 0.4994 & $9.39 \mathrm{E}-10$ \\
\hline rs12419948 & $\mathrm{T}$ & A & 0.1746 & 0.5518 & $4.31 \mathrm{E}-15$ & 0.5069 & $4.90 \mathrm{E}-11$ & 0.3672 & $5.12 \mathrm{E}-06$ & 0.3773 & 3.39E-06 & 0.5367 & $2.74 \mathrm{E}-11$ \\
\hline rs925947 & G & $\mathrm{T}$ & 0.1746 & 0.5518 & $4.31 \mathrm{E}-15$ & 0.5069 & $4.90 \mathrm{E}-11$ & 0.3672 & $5.12 \mathrm{E}-06$ & 0.3773 & 3.39E-06 & 0.5367 & $2.74 \mathrm{E}-11$ \\
\hline rs16917204 & G & $C$ & 0.1746 & 0.5518 & $4.31 \mathrm{E}-15$ & 0.5069 & $4.90 \mathrm{E}-11$ & 0.3672 & $5.12 \mathrm{E}-06$ & 0.3773 & 3.39E-06 & 0.5367 & $2.74 \mathrm{E}-11$ \\
\hline rs10501087 & $\mathrm{T}$ & $C$ & 0.1746 & 0.5518 & $4.31 \mathrm{E}-15$ & 0.5069 & 4.90E-11 & 0.3672 & $5.12 \mathrm{E}-06$ & 0.3773 & 3.39E-06 & 0.5367 & $2.74 \mathrm{E}-11$ \\
\hline rs36070170 & $A$ & AT & 0.1746 & 0.5518 & $4.31 \mathrm{E}-15$ & 0.5069 & $4.90 \mathrm{E}-11$ & 0.3672 & $5.12 \mathrm{E}-06$ & 0.3773 & 3.39E-06 & 0.5367 & $2.74 \mathrm{E}-11$ \\
\hline rs4923463 & A & G & 0.1746 & 0.5518 & 4.31E-15 & 0.5069 & 4.90E-11 & 0.3672 & $5.12 \mathrm{E}-06$ & 0.3773 & 3.39E-06 & 0.5367 & $2.74 \mathrm{E}-11$ \\
\hline rs11030099 & C & A & 0.1746 & 0.5518 & $4.31 \mathrm{E}-15$ & 0.5069 & $4.90 \mathrm{E}-11$ & 0.3672 & $5.12 \mathrm{E}-06$ & 0.3773 & 3.39E-06 & 0.5367 & $2.74 \mathrm{E}-11$ \\
\hline rs11030100 & G & $\mathrm{T}$ & 0.1746 & 0.5518 & 4.31E-15 & 0.5069 & 4.90E-11 & 0.3672 & $5.12 \mathrm{E}-06$ & 0.3773 & 3.39E-06 & 0.5367 & $2.74 \mathrm{E}-11$ \\
\hline rs4923464 & C & $\mathrm{T}$ & 0.1746 & 0.5518 & $4.31 \mathrm{E}-15$ & 0.5069 & 4.90E-11 & 0.3672 & $5.12 \mathrm{E}-06$ & 0.3764 & 3.60E-06 & 0.5367 & $2.74 \mathrm{E}-11$ \\
\hline rs113145808 & $\mathrm{T}$ & C & 0.1746 & 0.5075 & $1.20 \mathrm{E}-12$ & 0.4758 & $9.88 \mathrm{E}-10$ & 0.3694 & 4.47E-06 & 0.4334 & $6.39 \mathrm{E}-08$ & 0.4994 & $9.39 \mathrm{E}-10$ \\
\hline rs12801337 & G & A & 0.1746 & 0.5075 & $1.20 \mathrm{E}-12$ & 0.4758 & $9.88 \mathrm{E}-10$ & 0.3694 & 4.47E-06 & 0.4334 & 6.39E-08 & 0.4994 & $9.39 \mathrm{E}-10$ \\
\hline rs12790234 & A & G & 0.1746 & 0.5075 & $1.20 \mathrm{E}-12$ & 0.4758 & $9.88 \mathrm{E}-10$ & 0.3694 & 4.47E-06 & 0.4334 & 6.39E-08 & 0.4994 & $9.39 \mathrm{E}-10$ \\
\hline rs4922793 & A & G & 0.1755 & 0.5019 & $2.69 \mathrm{E}-12$ & 0.4918 & $2.53 \mathrm{E}-10$ & 0.3694 & 4.47E-06 & 0.4451 & 2.86E-08 & 0.4782 & 5.83E-09 \\
\hline rs988748 & C & G & 0.8182 & -0.4983 & $3.49 \mathrm{E}-12$ & -0.4896 & $2.71 \mathrm{E}-10$ & -0.3755 & $3.02 \mathrm{E}-06$ & -0.4334 & $6.39 \mathrm{E}-08$ & -0.476 & 7.02E-09 \\
\hline rs10767664 & $\mathrm{T}$ & A & 0.8182 & -0.4983 & $3.49 \mathrm{E}-12$ & -0.4896 & $2.71 \mathrm{E}-10$ & -0.3755 & $3.02 \mathrm{E}-06$ & -0.4334 & $6.39 \mathrm{E}-08$ & -0.476 & 7.02E-09 \\
\hline rs2030323 & A & $C$ & 0.8182 & -0.4983 & $3.49 \mathrm{E}-12$ & -0.4896 & $2.71 \mathrm{E}-10$ & -0.3755 & $3.02 \mathrm{E}-06$ & -0.4334 & 6.39E-08 & -0.476 & 7.02E-09 \\
\hline rs6484320 & $\mathrm{T}$ & A & 0.8206 & -0.514 & $5.51 \mathrm{E}-13$ & -0.4896 & $2.71 \mathrm{E}-10$ & -0.3755 & $3.02 \mathrm{E}-06$ & -0.4334 & $6.39 \mathrm{E}-08$ & -0.497 & 1.16E-09 \\
\hline rs444654 & $\mathrm{T}$ & G & 0.8206 & -0.514 & $5.51 \mathrm{E}-13$ & -0.4896 & $2.71 \mathrm{E}-10$ & -0.3755 & $3.02 \mathrm{E}-06$ & -0.4334 & $6.39 \mathrm{E}-08$ & -0.497 & 1.16E-09 \\
\hline rs7926362 & A & C & 0.8221 & -0.5099 & $1.06 \mathrm{E}-12$ & -0.4896 & $2.71 \mathrm{E}-10$ & -0.3768 & $3.00 \mathrm{E}-06$ & -0.4352 & $6.21 \mathrm{E}-08$ & -0.497 & 1.16E-09 \\
\hline rs7103411 & C & $\mathrm{T}$ & 0.8230 & -0.5098 & $9.16 \mathrm{E}-13$ & -0.4896 & 2.71E-10 & -0.3847 & $1.63 \mathrm{E}-06$ & -0.4334 & 6.39E-08 & -0.48 & 5.03E-09 \\
\hline
\end{tabular}

Note: REF Reference allele; ALT Alternative allele; Freq Frequency; Corr_ $r$ Spearman correlation estimates, Correlations and $p$-values across some SNPs are identical due to presence within a haplotype block

other hand, SNP rs6265, previously discussed, is found on exon 8. One study found that the haplotype of rs6265, rs2049045, and rs11030104 were all significant in Apolipoprotein E (APOE4) non-carriers, and the collective disruption of transcription in these coding regions, caused by the shared effects of these polymorphisms, results in decreased $B D N F$ expression [22]. Thus, the combined effect of these three SNPs and diplotypes increases the risk for Alzheimer's disease development in APOE 4 non-carriers [22].

Along with previous research, our results here have highlighted that $B D N F$ expression can differ significantly across various brain regions. This expression is influenced by several genetic phenomenon, which includes the influence of shared SNPs. While we don't have psychiatric phenotype data available directly from the GTEx database, we were able to show that these SNPs can influence underlying biological functions. Ultimately, these alterations can result neuropsychiatric conditions.

\section{Conclusions}

Here, using the GTEx database, we have identified significant genotype-expression interactions for $B D N F$ across five human brain regions (cerebellum, cortex, nucleus accumbens, caudate, and cerebellar hemisphere). 
Although the magnitude of these alterations differed across the tested regions, there were 30 different SNPs in 2 haplotype blocks that were associated with alterations in expression across these 5 areas. Moving forward, these identified targets can be used in the development of possible treatments and therapies that aim to restore proper $B D N F$ signaling. Ultimately, these shared SNPs can also provide us with possible targets for treatment in neuropsychiatric condition disorders of compulsion, impulsivity, and addiction, including depression, obsessive-compulsive disorder, substance use disorders, and schizophrenia.

\section{Methods}

\section{Genotype-tissue expression (GTEx) database}

Supported by the National Institutes of Health, the GTEx dataset contains phenotypic and molecular data from around 1000 adult human subjects across 54 tissue types. These tissues range from blood and lung samples to brain tissue. A limited set of clinical and demographic factors are also included. Users can browse the database using portal tools to gather some information on their gene(s) of interest, variant information, and tissue expression quantitative trait loci (eQTL) data (https:// gtexportal.org/home/). Here, we applied for access to an additional restricted dataset that includes RNA-seq and DNA sequencing information through the National Center for Biotechnology Information's Database of Genotypes and Phenotypes (dbGaP;https://dbgap.ncbi.nlm. nih.gov/). After obtaining access, we limited our investigations to available single-nucleotide polymorphism (SNP) data and BDNF expression across five brain regions relevant to neuropsychiatric conditions, considering only those which had non-zero expression (measured as Transcripts Per kilobase [TPM]) for BDNF: cerebellum, cortex, nucleus accumbens, caudate, and cerebellar hemisphere. Of note, cerebellum and cerebellar hemisphere represent samples that were collected under different collection and processing procedures. To clarify, the "cerebellar hemisphere" region includes both the right and left cerebellar hemispheres that were sampled at Miami Brain Bank and preserved as fresh frozen tissue. The data obtained from the "cerebellum" region is made up of samples of the right cerebellum sampled at the main donor collection site and preserved in PAXgene fixative. Due to the nature of these sample collection procedures, this measures the differences between the right and left cerebellar hemispheres. For transparency and replicability, we have used the labeling as used in the GTEx database. All other brain regions were specifically sampled at Miami Brain Bank and preserved as fresh frozen tissue (https://www.gtexportal.org/home/ samplingSitePage).
After these regions were selected, we investigated the association of $B D N F$ genotype with expression, associations between expression and four clinical and demographic factors also known to be important for the development of neuropsychiatric conditions: age, sex, race, and body mass index (BMI) [59-63]. Then we assessed for SNPs that were associated with expression variations across all 5 brain regions.

\section{Data analysis}

Summary statistics were collected along with the median expression of $B D N F$ in each region. The association of $B D N F$ expression with sex and race were tested in each region using Kruskal-Wallis tests. Wilcoxon signed-rank test was used to test equality of median expression level of $B D N F$ between two paired brain regions. Associations of $B D N F$ expression with age, BMI, and number of alternative alleles of each of our SNPs of interest were measured for each region by Spearman correlation. We elected to use a conservative rank based test with false discovery rate (FDR) estimated by the Benjamini and Hochberg method, with a cutoff value was set to 0.1 (at most, $10 \%$ false positive) in each brain region [64]. All analyses were performed using R- 3.6.1.

\section{Abbreviations \\ BDNF: Brain-derived neurotrophic factor; SNP: Single-nucleotide polymorphism; Val66Met: Rs6265 single-nucleotide polymorphism; mRNA: Messenger RNA; APOE4: Apolipoprotein E}

\section{Supplementary Information}

The online version contains supplementary material available at https://doi. org/10.1186/s12864-021-07525-1.

\section{Additional file 1.}

\section{Acknowledgements}

The authors wish to thank Mr. Curtis Roby for his editorial assistance in the preparation of this manuscript.

\section{Authors' contributions}

PD, XC, and AGS designed and planned the experiment. PD and AGS drafted and revised the article. PD and XC prepared the Figs. XC and AGS critically reviewed the manuscript. All authors read and approved the final manuscript.

\section{Funding}

This research was funded by the Office of the Director, National Institutes of Health (OD), with National Institutes of Health/National Institute of Nursing Research Grant number R01NR017407-02S1 (PI: Stanfill).

\section{Availability of data and materials}

Individual investigators seeking access to GTEx-controlled data must apply through the National Center for Biotechnology Information's (NCBI) database of Genotypes and Phenotypes (dbGaP) at https://dbgap.ncbi.nlm.nih.gov/. The data used in this study were that included in the General Research Use set (phs000424.v8.p2.c1), NHGRI. 


\section{Declarations}

\section{Ethics approval and consent to participate}

Permission to use the controlled data of the set: General Research Use (phs000424.v8.p2.c1) was granted by the $\mathrm{NIH}$ through the Database of Genotypes and Phenotypes (dbGaP) system under dbGaP Project \#23636. Detailed enrollment and consent verification for samples in the GTEx dataset can be found on download from https://biospecimens.cancer.gov/resources/ sops/library.asp.

This project was approved under the designation of non-human subject research by the Institutional Review Board of the University of Tennessee Health Science Center (\#19-06937-NHSR).

\section{Consent for publication}

Not applicable; non-human subjects research.

\section{Competing interests}

The authors declare no competing interests.

\section{Author details}

'Department of Anatomy and Neurobiology, College of Graduate Health Sciences, University of Tennessee Health Science Center, 920 Madison Ave. \#807, Memphis, TN 38163, USA. ${ }^{2}$ Department of Acute and Tertiary Care, College of Nursing, University of Tennessee Health Science Center, 874 Union Ave. \#120J, Memphis, TN 38163, USA.

Received: 11 November 2020 Accepted: 11 March 2021 Published online: 23 March 2021

\section{References}

1. Nakagomi A, Okada S, Yokoyama M, Yoshida Y, Shimizu I, Miki T, Kobayashi $Y$, Minamino T. Role of the central nervous system and adipose tissue BDNF/TrkB axes in metabolic regulation. NPJ Aging Mechof Dis. 2015;1(1): 15009.

2. Numakawa T, Suzuki S, Kumamaru E, Adachi N, Richards M, Kunugi H. BDNF function and intracellular signaling in neurons. Histol Histopathol. 2010; 25(2):237-58. https://doi.org/10.14670/HH-25.237.

3. Habtemariam $\mathrm{S}$. The brain-derived neurotrophic factor in neuronal plasticity and neuroregeneration: new pharmacological concepts for old and new drugs. Neural Regen Res. 2018;13(6):983-4. https://doi.org/10.4103/1673-53 74.233438 .

4. Wurzelmann M, Romeika J, Sun D. Therapeutic potential of brain-derived neurotrophic factor (BDNF) and a small molecular mimics of BDNF for traumatic brain injury. Neural Regen Res. 2017;12(1):7-12. https://doi.org/1 0.4103/1673-5374.198964.

5. Lima Giacobbo B, Doorduin J, Klein HC, Dierckx RAJO, Bromberg E, de Vries EFJ. Brain-derived Neurotrophic factor in brain disorders: focus on Neuroinflammation. Mol Neurobiol. 2019;56(5):3295-312. https://doi.org/10.1 007/s12035-018-1283-6.

6. Cattaneo A, Cattane N, Begni V, Pariante CM, Riva MA. The human BDNF gene: peripheral gene expression and protein levels as biomarkers for psychiatric disorders. Transl Psychiatry. 2016;6(11):e958. https://doi.org/10.1 038/tp.2016.214

7. Polyakova M, Stuke K, Schuemberg K, Mueller K, Schoenknecht P, Schroeter ML. BDNF as a biomarker for successful treatment of mood disorders: a systematic \& quantitative meta-analysis. J Affect Disord. 2015;174:432-40. https://doi.org/10.1016/j.jad.2014.11.044.

8. Boulle F, van den Hove DLA, Jakob SB, Rutten BP, Hamon M, van Os J, Lesch KP, Lanfumey L, Steinbusch HW, Kenis G. Epigenetic regulation of the BDNF gene: implications for psychiatric disorders. Mol Psychiatry. 2012;17(6): 584-96. https://doi.org/10.1038/mp.2011.107.

9. Nestor PG, O'Donovan K, Lapp HE, Hasler VC, Boodai SB, Hunter R. Risk and protective effects of serotonin and BDNF genes on stress-related adult psychiatric symptoms. Neurobiol Stress. 2019;11:100186. https://doi.org/10.1 016/j.ynstr.2019.100186.

10. Fumagalli F, Racagni G, Riva MA. The expanding role of BDNF: a therapeutic target for Alzheimer's disease? Pharmacogenomics J. 2006;6(1):8-15. https:// doi.org/10.1038/sj.tpj.6500337.

11. Issa G, Wilson C, Terry AV, Pillai A. An inverse relationship between cortisol and BDNF levels in schizophrenia: data from human postmortem and animal studies. Neurobiol Dis. 2010;39(3):327-33. https://doi.org/10.1016/j. nbd.2010.04.017.

12. Pandya CD, Kutiyanawalla A, Pillai A. BDNF-TrkB signaling and neuroprotection in schizophrenia. Asian J Psychiatr. 2013;6(1):22-8. https:// doi.org/10.1016/j.ajp.2012.08.010.

13. Weickert CS, Hyde TM, Lipska BK, Herman MM, Weinberger DR, Kleinman JE Reduced brain-derived neurotrophic factor in prefrontal cortex of patients with schizophrenia. Mol Psychiatry. 2003;8(6):592-610. https://doi.org/10.103 8/sj.mp.4001308.

14. Durany N, Michel T, Zöchling R, Boissl KW, Cruz-Sánchez FF, Riederer P, Thome J. Brain-derived neurotrophic factor and neurotrophin 3 in schizophrenic psychoses. Schizophr Res. 2001;52(1):79-86. https://doi.org/1 0.1016/S0920-9964(00)00084-0.

15. Su H, Tao J, Zhang J, Xie Y, Han B, Lu Y, Sun H, Wei Y, Wang Y, Zhang Y, Zou S, Wu W, Zhang J, Xu K, Zhang X, He J. The analysis of BDNF gene polymorphism haplotypes and impulsivity in methamphetamine abusers. Compr Psychiatry. 2015;59:62-7. https://doi.org/10.1016/j.comppsych.2015. 02.017.

16. Han EJ, Kim YK, Hwang JA, Kim SH, Lee HJ, Yoon HK, Na KS. Evidence for association between the brain-derived Neurotrophic factor gene and Panic disorder: a novel haplotype analysis. Psychiatry Investig. 2015;12(1):112-7. https://doi.org/10.4306/pi.2015.12.1.112.

17. Boiocchi C, Maggioli E, Zorzetto M, Sinforiani E, Cereda C, Ricevuti G, Cuccia M. Brain-derived neurotrophic factor gene variants and Alzheimer disease: an association study in an Alzheimer disease Italian population. Rejuvenation Res. 2013;16(1):57-66. https://doi.org/10.1089/rej.2012.1381.

18. Varnäs K, Lawyer G, Jönsson EG, Kulle B, Nesvåg R, Hall H, Terenius L, Agartz I. Brain-derived neurotrophic factor polymorphisms and frontal cortex morphology in schizophrenia. Psychiatr Genet. 2008;18(4):177-83. https:// doi.org/10.1097/YPG.0b013e3283050a94.

19. Schumacher J, Jamra RA, Becker T, Ohlraun S, Klopp N, Binder EB, Schulze TG, Deschner M, Schmäl C, Höfels S, Zobel A, Illig T, Propping P, Holsboer F, Rietschel M, Nöthen MM, Cichon S. Evidence for a relationship between genetic variants at the brain-derived neurotrophic factor (BDNF) locus and major depression. Biol Psychiatry. 2005;58(4):307-14. https://doi.org/10.1016/ j.biopsych.2005.04.006.

20. Sears C, Markie D, Olds R, Fitches A. Evidence of associations between bipolar disorder and the brain-derived neurotrophic factor (BDNF) gene. Bipolar Disord. 2011;13(7-8):630-7. https://doi.org/10.1111/j.1399-5618.2011. 00955.x.

21. Hall D, Dhilla A, Charalambous A, Gogos JA, Karayiorgou M. Sequence variants of the brain-derived neurotrophic factor (BDNF) gene are strongly associated with obsessive-compulsive disorder. Am J Hum Genet. 2003; 73(2):370-6. https://doi.org/10.1086/377003.

22. Huang R, Huang J, Cathcart H, Smith S, Poduslo SE. Genetic variants in brain-derived neurotrophic factor associated with Alzheimer's disease. J Med Genet. 2007:44(2):e66. https://doi.org/10.1136/jmg.2006.044883.

23. Lee JS, Cheong HS, Shin HD. BMI prediction within a Korean population. PeerJ. 2017:5:e3510. https://doi.org/10.7717/peerj.3510.

24. Wang T, Moon JY, Wu Y, Amos Cl, Hung RJ, Tardon A, Andrew A, Chen C, Christiani DC, Albanes D, Heijden EHFM, Duell E, Rennert G, Goodman G, Liu G, Mckay JD, Yuan JM, Field JK, Manjer J, Grankvist K, Kiemeney LA, Marchand LL, Teare MD, Schabath MB, Johansson M, Aldrich MC, Davies M, Johansson M, Tsao MS, Caporaso N, Lazarus P, Lam S, Bojesen SE, Arnold S, Wu X, Zong X, Hong YC, Ho GYF. Pleiotropy of genetic variants on obesity and smoking phenotypes: results from the Oncoarray project of the international lung Cancer consortium. PLoS One. 2017;12(9):e0185660. https://doi.org/10.1371/journal.pone.0185660.

25. Sha'ari HM, Haerian BS, Baum L, Tan HJ, Rafia MH, Kwan P, Cherny SS, Sham PC, Gui H, Raymond AA, et al. Association of BDNF polymorphisms with the risk of epilepsy: a multicenter study. Mol Neurobiol. 2016;53(5):2869-77. https://doi.org/10.1007/s12035-015-9150-1.

26. Gamero-Villarroel C, Gordillo I, Carrillo JA, García-Herráiz A, Flores I, Jiménez M, Monge M, Rodríguez-López R, Gervasini G. BDNF genetic variability modulates psychopathological symptoms in patients with eating disorders. Eur Child Adolesc Psychiatry. 2014;23(8):669-79. https://doi.org/10.1007/ s00787-013-0495-6.

27. Ivanova MA, Christova TN, Asan TS, Djurova NA, Alexiev SS, Kostov CS, Chorbov VM, Stoyanova VS, Onchev GN, Kancheva DM, Krastev SK, Vladimirova RK, Kremensky IM, Mitev V, Milanova VK, Kaneva RP. Evidence of an association between bipolar disorder and rs16917237 in the BDNF gene 
in a Bulgarian sample. Psychiatr Genet. 2013;23(3):141-2. https://doi.org/10.1 097/YPG.0b013e32835d7225.

28. Louhivuori V, Arvio M, Soronen P, Oksanen V, Paunio T, Castrén ML. The Val66Met polymorphism in the BDNF gene is associated with epilepsy in fragile X syndrome. Epilepsy Res. 2009;85(1):114-7. https://doi.org/10.1016/j. eplepsyres.2009.01.005.

29. Beuten J, Ma JZ, Payne TJ, Dupont RT, Quezada P, Huang W, Crews KM, Li MD. Significant association of BDNF haplotypes in European-American male smokers but not in European-American female or African-American smokers. Am J Med Genet B Neuropsychiatr Genet. 2005;139B(1):73-80. https://doi.org/10.1002/ajmg.b.30231.

30. Borroni B, Grassi M, Archetti S, Costanzi C, Bianchi M, Caimi L, Caltagirone C, Di Luca M, Padovani A. BDNF genetic variations increase the risk of Alzheimer's disease-related depression. J Alzheimers Dis. 2009;18(4):867-75. https://doi.org/10.3233/JAD-2009-1191.

31. Müller DJ, de Luca V, Sicard T, King N, Strauss J, Kennedy JL. Brain-derived neurotrophic factor (BDNF) gene and rapid-cycling bipolar disorder: familybased association study. Br J Psychiatry. 2006;189(4):317-23. https://doi.org/1 0.1192/bjp.bp.105.010587.

32. Chan $C B$, Ye K. Sex differences in brain-derived neurotrophic factor signaling and functions. J Neurosci Res. 2017:95(1-2):328-35. https://doi. org/10.1002/jnr.23863.

33. Kight KE, McCarthy MM. Sex differences and estrogen regulation of BDNF gene expression, but not propeptide content, in the developing hippocampus. J Neurosci Res. 2017;95(1-2):345-54. https://doi.org/10.1002/ jnr.23920.

34. Wei $Y-C$, Wang $S-R, X u X-H$. Sex differences in brain-derived neurotrophic factor signaling: functions and implications. J Neurosci Res. 2017;95(1-2): 336-44. https://doi.org/10.1002/jnr.23897.

35. Croll SD, Ip NY, Lindsay RM, Wiegand SJ. Expression of BDNF and trkB as a function of age and cognitive performance. Brain Res. 1998;812(1):200-8. https://doi.org/10.1016/50006-8993(98)00993-7.

36. Oh $\mathrm{H}$, Lewis DA, Sibille E. The role of BDNF in age-dependent changes of excitatory and inhibitory synaptic markers in the human prefrontal cortex. Neuropsychopharmacology. 2016;41(13):3080-91. https://doi.org/10.1038/ npp.2016.126.

37. Erickson Kl, Prakash RS, Voss MW, Chaddock L, Heo S, McLaren M, Pence BD, Martin SA, Vieira VJ, Woods JA, McAuley E, Kramer AF. Brain-derived Neurotrophic factor is associated with age-related decline in hippocampal volume. J Neurosci. 2010;30(15):5368-75. https://doi.org/10.1523/JNEUROSCI. 6251-09.2010

38. Willsey AJ, Sanders Stephan J, Li M, Dong S, Tebbenkamp Andrew T, Muhle Rebecca A, Reilly Steven K, Lin L, Fertuzinhos S, Miller Jeremy A, et al. Coexpression networks implicate human Midfetal deep cortical projection neurons in the pathogenesis of autism. Cell. 2013;155(5):997-1007. https:// doi.org/10.1016/j.cell.2013.10.020.

39. Hofer M, Pagliusi SR, Hohn A, Leibrock J, Barde YA. Regional distribution of brain-derived neurotrophic factor mRNA in the adult mouse brain. EMBO J. 1990;9(8):2459-64. https://doi.org/10.1002/j.1460-2075.1990.tb07423.X.

40. Lee B-H, Kim Y-K. The roles of BDNF in the pathophysiology of major depression and in antidepressant treatment. Psychiatry Investig. 2010;7(4): 231-5. https://doi.org/10.4306/pi.2010.7.4.231.

41. Yu H, Chen Z-Y. The role of BDNF in depression on the basis of its location in the neural circuitry. Acta Pharmacol Sin. 2011;32(1):3-11. https://doi.org/1 0.1038/aps.2010.184.

42. Chen ZY, Patel PD, Sant G, Meng CX, Teng KK, Hempstead BL, Lee FS. Variant brain-derived neurotrophic factor (BDNF) (Met66) alters the intracellular trafficking and activity-dependent secretion of wild-type BDNF in neurosecretory cells and cortical neurons. J Neurosci. 2004;24(18):440111. https://doi.org/10.1523/JNEUROSCI.0348-04.2004.

43. Ellison-Wright I, Bullmore E. Anatomy of bipolar disorder and schizophrenia: a meta-analysis. Schizophr Res. 2010;117(1):1-12. https://doi.org/10.1016/j. schres.2009.12.022.

44. Pezawas L, Verchinski BA, Mattay VS, Callicott JH, Kolachana BS, Straub RE, Egan MF, Meyer-Lindenberg A, Weinberger DR. The brain-derived neurotrophic factor val66met polymorphism and variation in human cortical morphology. J Neurosci. 2004;24(45):10099-102. https://doi.org/10.1523/ JNEUROSCI.2680-04.2004.

45. Teh CA, Lee T-S, Kuchibhatla M, Ashley-Koch A, Macfall J, Krishnan R, Beyer J. Bipolar disorder, brain-derived neurotrophic factor (BDNF) Val66Met polymorphism and brain morphology. PLoS One. 2012;7(7):e38469. https:// doi.org/10.1371/journal.pone.0038469.

46. Rakofsky JJ, Ressler KJ, Dunlop BW. BDNF function as a potential mediator of bipolar disorder and post-traumatic stress disorder comorbidity. Mol Psychiatry. 2012;17(1):22-35. https://doi.org/10.1038/mp.2011.121.

47. Kohli MA, Salyakina D, Pfennig A, Lucae S, Horstmann S, Menke A, Kloiber S, Hennings J, Bradley BB, Ressler KJ, Uhr M, Müller-Myhsok B, Holsboer F, Binder EB. Association of genetic variants in the neurotrophic receptorencoding gene NTRK2 and a lifetime history of suicide attempts in depressed patients. Arch Gen Psychiatry. 2010;67(4):348-59. https://doi.org/1 0.1001/archgenpsychiatry.2009.201.

48. Smith EN, Bloss CS, Badner JA, Barrett T, Belmonte PL, Berrettini W, Byerley W, Coryell W, Craig D, Edenberg HJ, Eskin E, Foroud T, Gershon E, Greenwood TA, Hipolito M, Koller DL, Lawson WB, Liu C, Lohoff F, McInnis MG, McMahon FJ, Mirel DB, Murray SS, Nievergelt C, Nurnberger J, Nwulia EA, Paschall J, Potash JB, Rice J, Schulze TG, Scheftner W, Panganiban C, Zaitlen N, Zandi PP, Zöllner S, Schork NJ, Kelsoe JR. Genome-wide association study of bipolar disorder in European American and African American individuals. Mol Psychiatry. 2009;14(8):755-63. https://doi.org/10.1 038/mp.2009.43.

49. Hsu PK, Xu B, Mukai J, Karayiorgou M, Gogos JA. The BDNF Val66Met variant affects gene expression through miR-146b. Neurobiol Dis. 2015;77:228-37. https://doi.org/10.1016/.j.nbd.2015.03.004.

50. C-h P, Kim J, Namgung E, Lee D-W, Kim GH, Kim M, Kim N, Kim TD, Kim S, Lyoo IK, et al. The BDNF val66met polymorphism affects the vulnerability of the brain structural network. Front Hum Neurosci. 2017;11(400).

51. Egan MF, Kojima M, Callicott JH, Goldberg TE, Kolachana BS, Bertolino A, Zaitsev E, Gold B, Goldman D, Dean M, Lu B, Weinberger DR. The BDNF val66met polymorphism affects activity-dependent secretion of BDNF and human memory and hippocampal function. Cell. 2003;112(2):257-69. https://doi.org/10.1016/S0092-8674(03)00035-7.

52. Kuczewski N, Porcher C, Gaiarsa JL. Activity-dependent dendritic secretion of brain-derived neurotrophic factor modulates synaptic plasticity. Eur J Neurosci. 2010;32(8):1239-44. https://doi.org/10.1111/j.1460-9568.2010.073 78.x.

53. Kim EJ, Kim YK. 196G/a of the brain-derived Neurotrophic factor gene polymorphisms predicts suicidal behavior in schizophrenia patients. Psychiatry Investig. 2018;15(7):733-8. https://doi.org/10.30773/pi.2018.02.27.

54. Lettice LA, Heaney SJ, Purdie LA, Li L, de Beer P, Oostra BA, Goode D, Elgar $G$, Hill RE, de Graaff E. A long-range Shh enhancer regulates expression in the developing limb and fin and is associated with preaxial polydactyly. Hum Mol Genet. 2003;12(14):1725-35. https://doi.org/10.1093/hmg/ddg180.

55. Seo S, Takayama K, Uno K, Ohi K, Hashimoto R, Nishizawa D, Ikeda K, Ozaki $\mathrm{N}$, Nabeshima T, Miyamoto Y, Nitta A. Functional analysis of deep intronic SNP rs13438494 in intron 24 of PCLO gene. PLoS One. 2013;8(10):e76960. https://doi.org/10.1371/journal.pone.0076960.

56. Kimchi-Sarfaty C, Oh JM, Kim IW, Sauna ZE, Calcagno AM, Ambudkar SV, Gottesman MM. A "silent" polymorphism in the MDR1 gene changes substrate specificity. Science. 2007;315(5811):525-8. https://doi.org/10.1126/ science.1135308.

57. Zhang Z, Miteva MA, Wang L, Alexov E. Analyzing effects of naturally occurring missense mutations. Comput Math Methods Med. 2012;2012: 805827.

58. Hing B, Sathyaputri L, Potash JB. A comprehensive review of genetic and epigenetic mechanisms that regulate BDNF expression and function with relevance to major depressive disorder. Am J Med Genet B Neuropsychiatr Genet. 2018;177(2):143-67. https://doi.org/10.1002/ajmg.b.32616.

59. Arvanitakis Z, Capuano AW, Bennett DA, Barnes LL. Body mass index and decline in cognitive function in older black and white persons. J Gerontol A Biol Sci Med Sci. 2018;73(2):198-203. https://doi.org/10.1093/gerona/glx152.

60. Roceri M, Cirulli F, Pessina C, Peretto P, Racagni G, Riva MA. Postnatal repeated maternal deprivation produces age-dependent changes of brainderived neurotrophic factor expression in selected rat brain regions. Biol Psychiatry. 2004;55(7):708-14. https://doi.org/10.1016/j.biopsych.2003.12.011.

61. Schwarz JM, Bilbo SD. Sex, glia, and development: interactions in health and disease. Horm Behav. 2012;62(3):243-53. https://doi.org/10.1016/.jyhbeh.2 012.02.018.

62. Vaskinn A, Sundet K, Simonsen C, Hellvin T, Melle I, Andreassen OA: Sex differences in neuropsychological performance and social functioning in schizophrenia and bipolar disorder. In: American Psychological Association; 2011: 499-510. 
63. Welsh KA, Fillenbaum G, Wilkinson W, Heyman A, Mohs RC, Stern Y, Harrell LM, Edland SD, Beekly D. Neuropsychological test performance in AfricanAmerican* and white patients with Alzheimer\&\#039;s disease. Neurology. 1995;45(12):2207, Neuropsychological test performance in African-American* and white patients with Alzheimer's disease-11. https://doi.org/10.1212/ WNL.45.12.2207.

64. Benjamini Y, Hochberg Y. Controlling the false discovery rate: a practical and powerful approach to multiple testing. J R Stat Soc Ser B Methodol. 1995;57(1):289-300.

\section{Publisher's Note}

Springer Nature remains neutral with regard to jurisdictional claims in published maps and institutional affiliations.

- fast, convenient online submission

- thorough peer review by experienced researchers in your field

- rapid publication on acceptance

- support for research data, including large and complex data types

- gold Open Access which fosters wider collaboration and increased citations

- maximum visibility for your research: over $100 \mathrm{M}$ website views per year

At $\mathrm{BMC}$, research is always in progress. 